\title{
Model Pembelajaran Take and Give Berbantuan Media Mind Mapping Berpengaruh Terhadap Hasil Belajar IPA
}

\author{
I Ketut Wahyudi Seputra*1 iD \\ ${ }^{1}$ Prodi Pendidikan Guru Sekolah Dasar, Universitas Pendidikan Ganesha, Bali, Indonesia \\ *Corresponding author: wahyudiputra2101@gmail.com
}

\begin{abstract}
Abstrak
Penelitian ini bertujuan untuk mengetahui pengaruh model pembelajaran Take and Give berbantuan media Mind Mapping terhadap hasil belajar IPA siswa kelas V SD. Penelitian ini merupakan penelitian eksperimen semua atau quasi experiment dengan disain nonequivalent post-test only control group designe. Sampel pada penelitian ini berjumlah 25 siswa kelas $\mathrm{V}$ yang teridiri dari kelas eksperimen yaitu SD Negeri 2 Bila sebanyak 11 siswa dan dari kelas kontrol yaitu SD Negeri 2 Bengkala sebanyak 14 siswa yang diperoleh melalui teknik group desain random sampling. Data pada penelitian ini adalah skor hasil belajar IPA siswa yang dikumpulkan dengan metode tes dalam bentuk pilihan ganda dengan 25 butir soal. Data dianalisis statistik deskriptif dan statistik inferensial. Hasil penelitian terdapat pengaruh yang signifikan terhadap siswa yang dibelajarakan menggunakan model pembelajaran Take and Give berbantuan media Mind Mapping yang dibuktikan dengan hasil analisis uji-t yaitu (thitung $=3,29>$ tabel $=1,714$ ). Berdasarkan hasil analisis uji-t dapat disimpulkan bahwa terdapat pengaruh yang signifikan model pembelajaran Take and Give berbantuan media Mind Mapping terhadap hasil belajar IPA siswa kelas V SD.
\end{abstract}

Kata kunci: Take and Give, Mind Mapping, Hasil Belajar IPA

\section{Abstract}

This study aims to determine the effect of the Mind and Mapping media-assisted Take and Give learning model on the learning outcomes of science students in grade $V$ elementary school. This research is an all-quasi-experimental study with a nonequivalent post-test only control group design design. The sample in this study amounted to 25 fifth grade students consisting of the experimental class namely SD Negeri 2 If as many as 11 students and from the control class namely SD Negeri 2 Bengkala as many as 14 students were obtained through random sampling design group techniques. The data in this study are the scores of students' science learning outcomes collected by the test method in the form of multiple choice with 25 items. Data were analyzed descriptive statistics and inferential statistics. The results of the study have a significant effect on students who are taught using the Mind and Mapping media assisted learning model as evidenced by the results of the t-test analysis (tcount $=3.29>$ ttable $=1.714$ ). Based on the results it was concluded that there was an significant influence of the Take and give learning model assisted by Mind Mapping media on the learning outcomes of science students in grade V elementary school.

Keywords: Take and Give, Mind Mapping, Science Learning Outcomes

\section{Introduction}

Indonesia memiliki berbagai macam jenjang pendidikan, dimulai dari pendidikan dasar yaitu pendidikan yang paling bawah misalnya, Sekolah Dasar (SD), pendidikan menengah yaitu lanjutan dari pendidikan dasar misalnya Sekolah Menengah Pertama (SMP), Sekolah Menengah Atas (SMA), atau Sekolah Menengah Kejuruan (SMK). Pendidikan tinggi yaitu lanjutan dari pendidikan menengah misalnya, Diploma, Sarjana, Magister, dan Doktor. Yuliastini et al, (2015) menyatakan bahwa pendidikan merupakan usaha untuk mengembangkan dan membina potensi Sumber Daya Manusia (SDM) melalui berbagai macam kegiatan pembelajaran. Kualitas pendidikan dengan sendirinya akan tercemin dari kualitas sumber daya manusia, karena sumber daya manusia di Indonesia pada umumnya

$\begin{array}{lll}\text { History: } & \text { Publisher: Undiksha Press } \\ \text { Received } & : \text { 24 August } 2020 & \text { Licensed: This work is licensed under } \\ \text { Revised } & : \text { 1 September } 2020 & \\ \text { Accepted }: \text { : } 1 \text { October } 2020 & \text { a Creative Commons Attribution 3.0 License } \\ \text { Published }: 1 \text { Desember } 2020 & \end{array}$


masih rendah, dengan demikian kualitas pendidikan mayoritas masih rendah. Marliana et al, (2015) menyatakan bahwa pendidikan merupakan suatu hal yang sangat baik dalam kehidupan berbangsa dan bernegara. Kemajuan suatu Negara sangat ditentukan oleh maju mundurnya pendidikan di Negara tersebut. Untuk memajukan suatu Negara, tentunya pendidikan di Negara tersebut harus bermutu. Salah satu upaya untuk meningkatkan mutu pendidikan adalah melalui peningkatan kualitas pembelajaran (Mukhid, 2007). Pendidikan di Indonesia memang masih tergolong rendah bila dibandingkan dengan negara-negara lain (Karim, 2018; Ratih Sulistyastuti, 2007). Sangat terlihat jelas bahwa masalah yang serius dalam meningkatkan mutu pendidikan di Indonesia adalah rendahnya mutu pendidikan di berbagai jenjang pendidikan, baik pendidikan dasar maupun pendidikan tinggi. Salah satu penyebab rendahnya mutu pendidikan di Indonesia yaitu rendahnya kualitas pendidikan disebabkan lemahnya kemampuan para guru untuk menggali potensi siswa dalam proses pembelajaran dan upaya guru dalam meningkatkan hasil belajar siswa. Jadi dapat disimpulkan bahwa pendidikan adalah usaha untuk mengembangkan potensi sumber daya manusia. Jika suatu Negara sudah memiliki sumber daya manusia yang berkualitas, maka Negara tersebut akan menjadi Negara yang maju. Untuk menciptakan sumber daya manusia yang berkualitas, tentunya pendidikan di Negara tersebut harus bermutu. Salah satu mata pelajaran yang harus dikembangkan pada jenjang pendidikan dasar terutama pada tingkat Sekolah Dasar (SD) adalah mata pelajaran IPA. Pembelajaran di Sekolah Dasar (SD) mampu memberikan kesempatan untuk memupuk rasa ingin tahu siswa secara ilmiah. Hal ini mampu membantu siswa mengembangkan kemampuan bertanya dan mencari jawaban berdasarkan bukti serta mengembangkan cara berpikir ilmiah. IPA tidak hanya merupakan kumpulan pengetahuan atau kumpulan fakta, konsep, prinsip, atau teori semata, tetapi IPA juga menyangkut tentang cara kerja, cara berpikir dan cara memecahkan masalah.

Berdasarkan hasil observasi yang dilaksanakan pada Gugus III Kecamatan Kubutambahan Kabupaten Buleleng pada hari Jumat, 18 Oktober 2019 bahwa masih banyak masalah yang dihadapai pendidik maupun peserta didik dalam proses pembelajaran. Semua sekolah di Gugus III Kecamatan Kubutambahan Kabupaten Buleleng memiliki masalah yang hampir sama, masalah tersebut antara lain; 1) keaktifan siswa dalam belajar sangat kurang. Hal ini terlihat dari proses pembelajaran, dimana dalam pembelajaran banyak siswa yang terlihat hanya duduk dan mencatat tanpa ada yang ingin menyampaikan pendapat ataupun bertanya tentang materi yang mereka pelajari, 2) kurangnya motivasi belajar yang diberikan oleh guru kepada peserta didik. Kurangnya motivasi belajar dapat menyebabkan rendahnya semangat siswa dalam belajar dan kebanyakan siswa tidak memiliki gairah untuk belajar, 3) kurangnya penerapan model pembelajaran yang bervariasi didalam kelas. Dalam proses pembelajaran, biasanya guru hanya menggunakan model Teacher Center (berpusat pada guru) sehingga proses pembelajaran hanya didominasi oleh guru sementara peserta didik hanya duduk mendengar dan mencatat apa yang disampaikan oleh guru, 4) kurangnya konsentrasi siswa dalam mengikuti proses pembelajaran, 5) kurangnya media dan alat peraga yang digunakan oleh guru pada proses pembelajaran, 6) hasil belajar IPA masih kurang. Dari kelima masalah yang telah dipaparkan di atas, tentu sangat mempengaruhi hasil belajar yang diperoleh oleh peserta didik. Hal ini dari dilihat dari hasil UTS pada mata pelajaran IPA. Sebagian dari peserta didik kelas V masih mendapatkan nilai dibawah Kriteria Ketuntasan Minimum (KKM). Hasil belajar tersebut dapat dilihat pada Tabel 1.

Tabel 1 pada Ulangan Tengah Semester (UTS) mata pelajaran IPA dengan KKM 65, dapat dijelaskan bahwa pada kelas V SDN 1 Bengkala peserta didik yang memperoleh nilai diatas KKM berjumlah 4 orang dan yang dibawah KKM sebanyak 10 orang, pada kelas $\mathrm{V}$ SDN 2 Bengkala peserta didik yang memperoleh nilai diatas KKM berjumlah 5 orang dan yang dibawah KKM sebanyak 9 orang, pada kelas V SDN 1 Bila peserta didik yang memperoleh nilai diatas KKM berjumlah 8 orang dan yang dibawah KKM sebanyak 11 orang, 
dan pada kelas V SDN 2 Bila peserta didik yang memperoleh nilai diatas KKM berjumlah 5 orang dan yang dibawah KKM sebanyak 6 orang.

Tabel 1. Rekapitulasi Nilai Ulangan Tengah Semester IPA Siswa kelas V Gugus III Kecamatan Kubutambahan Kabupaten Buleleng

\begin{tabular}{|c|c|c|c|c|c|c|}
\hline \multirow{2}{*}{$\begin{array}{l}\text { No } \\
\cdot\end{array}$} & \multirow{2}{*}{ Nama Sekolah } & \multirow{2}{*}{ Kelas } & \multirow{2}{*}{$\begin{array}{l}\text { Jumlah } \\
\text { Siswa }\end{array}$} & \multirow{2}{*}{$\begin{array}{l}\text { KKM } \\
\text { Sekolah }\end{array}$} & \multicolumn{2}{|c|}{$\begin{array}{ll}\text { Jumlah } & \text { Siswa } \\
\text { Mencapai KKM }\end{array}$} \\
\hline & & & & & Tuntas & Tidak Tuntas \\
\hline 1 & SDN 1 Bengkala & V & 14 & 65 & 4 & 10 \\
\hline 2 & SDN 2 Bengkala & $\mathrm{V}$ & 14 & 65 & 5 & 9 \\
\hline 3 & SDN 1 Bila & $\mathrm{V}$ & 19 & 65 & 8 & 11 \\
\hline 4 & SDN 2 Bila & V & 11 & 65 & 5 & 6 \\
\hline \multicolumn{2}{|c|}{ Jumlah } & & 58 & & 20 & 38 \\
\hline
\end{tabular}

Berdasarkan permasalahan yang ditemukan pada kelas V di Gugus III Kecamatan Kubutambahan Kabupaten Buleleng, yaitu masih banyak peserta didik mendapatkan nilai di bawah KKM pada pelajaran IPA, maka perlu diterapkannya model pembelajaran yang mampu meningkatkan pengetahuan dan hasil belajar siswa. Salah satu model pembelajaran yang cocok digunakan adalah model pemebelajaran memberi dan menerima (Take and Give). Model pembelajaran Take and Give adalah model pembelajaran yang memiliki sintaks pembelajaran dengan menggunakan kartu yang berisi nama siswa, bahan belajar, dan sajian materi. Model Take and Give adalah model pembelajaran yang membuat peserta didik aktif dalam pembelajaran, dimana peserta didik mengambil dan memberi pelajaran pada peserta didik yang lain, sehingga diharapkan peserta didik dapat menguasai lebih banyak materi pelajaran dengan mengajarkan pada teman sebayanya, (Luritawaty, 2018; Sela et al., 2018). Penerapan model pembelajaran Take and Give setiap siswa diminta untuk berdiri dan mencari teman lalu saling menginformasikan tentang materi atau pengetahuannya kepada siswa lain, kemudian mencatat apa yang diperolehnya pada kartu. Dewi, et.al (2014) menyatakan bahwa model Take and Give memiliki kelebihan, yaitu 1) model pembelajaran ini tidak bersifat kaku, karena guru boleh memodifikasi lagi penggunaan model pembelajaran ini sesuai dengan keinginan, kebutuhan, serta situasi pembelajaran, 2) materi akan terarah, karena guru terlebih dahulu menjabarkan uraian materi sebelum kartu dibagikan kepada siswa, 3) melatih siswa dalam bekerja sama dan menghargai kemampuan siswa lain, 4) melatih siswa untuk berinteraksi secara baik dengan teman sekelasnya, 5) dapat meningkatkan tanggung jawab siswa, sebab setiap siswa diminta untuk bertanggung jawab atas kartu yang didapat. Tidak hanya model yang perlu diperhatikan dalam proses pembelajaran namun, adanya media juga akan mendukung keberhasilan dalam proses pembelajaran.

Media pembelajaran adalah seluruh alat dan bahan yang dapat digunakan dalam mencapai tujuan pendidikan seperti radio, televisi, buku, Koran, majalah, dan sebagainya (Arsyad \& Fatmawati, 2018). Media dalam proses pembelajaran dapat membangkitkan minat dan rasa ingin tahu yang baru, menumbuhkan motivasi dan rangsangan kegiatan belajar, serta membawa pengaruh psikologis terhadap pembelajaran (Arisantiani et al., 2017; Khotimah et al., 2020). Media pembelajaran yang sesuai dengan kebutuhan kegiatan pembelajaran akan menciptakan suatu kegiatan pembelajaran yang efektif dan efisien sehingga materi yang disampaikan oleh guru kepada siswa bisa diserap secara optimal (Melasarianti et al., 2019; Sapriyah, 2019; Suaeb et al., 2018). Salah satu media yang bisa digunakan adalah media Mind Mapping. Mind Mapping merupakan teknik yang paling baik dalam membantu proses berfikir otak secara teratur karena menggunakan teknik grafis yang berasal dari pemikiran manusia 
yang bermanfaat untuk menyediakan kunci-kunci universal sehingga membuka potensi otak (I. A. G \& Riastini, 2017; Van Hayus et al., 2014). Pembelajaran dengan mind mapping dapat meningkatkan ingatan dengan cara mengasosiasikan dan mengimajinasikan konsep, serta kata kunci yang saling berhubungan membuat siswa semakin mudah memahami materi (Sartono et al., 2018; Wicaksana, 2012). Mind Mapping dimulai dengan suatu konsep atau tema tunggal yang memiliki banyak pemikiran yang menjadi umpan kepada siswa untuk berpikir dan menghasilkan banyak gagasan mengenai suatu konsep atau tema tunggal tersebut (Darusman, 2014). Pembelajaran mind mapping adalah pembelajaran model baru untuk mencatat yang bekerjanya disesuaikan dengan bekerjanya dua belah otak (otak kiri dan otak kanan) (Rahayu, 2016; Suwitri et al., 2013). Mind Mapping merupakan salah satu teknik yang cocok untuk membantu daya ingat, karena didalamnya sudah terdapat pemetaan pikiran yang memuat kata kunci suatu topik sehingga tidak banyak lagi pembelajaran topik (Arsana et al., 2019).

Keberhasilan model pembelajaran Take and Give dalam pembelajaran IPA sudah dibuktikan dengan penelitian yang dilakukan oleh (Mutia, 2019) yang berjudul "Pengaruh Model Pembelajaran Take and Give terhadap Hasil Belajar IPA Kelas V SD Negeri 101874 Tumpatan Nibung Kecamatan Batang Kuis", dengan hasil yang diperoleh yaitu terdapat pengaruh yang signifikan dari model pembelajaran Take and Give Terhadap Hasil Belajar IPA Kelas V SD Negeri 101874 Tumpatan Nibung Kecamatan Batang Kuis, pada hasil belajar IPA. (Yuliastini et al, 2015) menyatakan bahwa, hasil belajar merupakan suatu prestasi belajar yang diperoleh peserta didik dari proses pembelajaran yang mampu merubah dan pembentuk tingkah laku peserta didik. Dalam meningkatkan hasil belajar peserta didik dapat dilakukan secara sistematis sehingga peserta didik mendapatkan perubahan yang positif.

Berdasarkan uraian di atas, model pembelajaran Take and Give berbantuan media Mind Mapping sangat efektif digunakan untuk meningkatkan hasil belajar IPA karena mampu membantu siswa dalam menggabungkan pengetahuan yang dimiliki oleh siswa dan pengetahuan yang dimiliki siswa lain. Oleh karena itu, tujuan penelitian ini adalah menganalisis pengaruh Model Pembelajaran Take and Give Berbantuan Media Mind Mapping terhadap Hasil Belajar IPA Siswa Kelas V Gugus III Kubutambahan Kabupaten Buleleng Tahun Pelajaran 2019/2020".

\section{Materials and Methods}

Desain penelitian yang digunakan dalam penelitian ini adalah eksperimen semu (quasi eksperiment) sebagai upaya untuk mengungkapkan hubungan sebab akibat dengan cara melibatkan kelompok eksperimen dan kelompok kontrol. Desain yang digunakan dalam eksperimen ini adalah desain kelompok kontrol yang hanya menggunakan Post-test saja (posttest only control group design). Dalam desain ini, subjek yang diambil dari populasi dikelompokan menjadi dua yaitu kelompok eksperimen dan kelompok kontrol secara acak. Kelompok eksperimen mendapatkan perlakuan pembelajaran dengan model pembelajaran Take and Give berbantuan media Mind Mapping. Sedangkan kelas kontrol mendapatkan perlakuan pembelajaran dengan model pembelajaran konvensional.

Populasi pada penelitian ini adalah seluruh siswa kelas V di Gugus III Kecamatan Kubutambahan Kabupaten Buleleng. Untuk mengetahui kesetaraan hasil belajar IPA siswa kelas $\mathrm{V}$ melalui nilai ulangan tengah semester disetiap sekolah, terlebih dahulu peneliti melakukan uji kesetaraan dengan menggunakan analisis varians satu jalur (Anava A) dengan berbantuan Microsoft Excel. Kriteria pengujiannya adalah jika Fhitung < Ftabel pada taraf signifikan 5\%, maka $\mathrm{H} 0$ diterima dan $\mathrm{H} 1$ ditolak yang artinya tidak terdapat perbedaan yang signifikan. Jika Fhitung > Ftabel maka H0 ditolak dan $\mathrm{H} 1$ diterima yang artinya terdapat perbedaan yang signifikan. Berdasarkan hasil analisis menggunakan ANAVA A pada taraf signifikan 5\%, diperoleh nilai Fhitung sebesar 2,04. Nilai Ftabel pada taraf signifikan 5\% dengan $\mathrm{dbA}=3$, dan dbdalam $=54$ adalah 2,78, artinya Fhitung $<$ Ftabel sehingga H0 diterima. 
Berdasarkan hasil analisis Anava A tersebut, dapat disimpulkan bahwa tidak terdapat perbedaan hasil belajar IPA siswa kelas V di Gugus III Kecamatan Kubutambahan Kabupaten Buleleng sehingga dengan kata lain dapat dikatakan setara

Sebagian data yang dipilih dari jumlah populasi yang dijadikan sebagai sumber data disebut sebagai sampel. (Agung, 2014) menyatakan bahwa "sampel adalah sebagian dari populasi yang diambil, yang dianggap mewakili seluruh populasi dan diambil menggunakan teknik tertentu". Dalam penelitian ini, teknik pengambilan sampel yang digunakan dalam memilih kelas eksperimen dan kelas kontrol adalah dengan cara sampel kelompok acak (Random Sampling). Penggunakaan Random Sampling untuk teknik pengambilan sampel dalam penelitian ini karena semua anggota pada populasi mempunyai kesempatan yang sama untuk dipilih menjadi sampel. Berdasarkan hasil sampel acak yang dilakukan oleh penulis, sekolah yang menjadi kelas eksperimen adalah SD Negeri 2 Bila, sedangkan kelas yang menjadi kelas kontrol adalah SD Negeri 2 Bengkala.

Data yang dikumpulkan pada penelitian ini adalah data hasil belajar IPA siswa kelas V. Metode yang digunakan untuk mengumpulkan data hasil belajar IPA adalah metode tes. Menurut (Agung, 2014) "tes adalah metode penelitian psikologis untuk memperoleh informasi tentang berbagai macam aspek dengan pengukuran (measurement) yang menghasilkan suatu deskripsi kuantitatif tentang aspek yang diteliti”. Instrument pengumpulan data yang digunakan untuk mengukur hasil belajar IPA siswa kelas V pada kelas eksperimen dan kelas kontrol adalah tes pilihan ganda. Tes yang akan digunakan untuk mengumpulkan data hasil belajar siswa kelas V disusun berdasarkan kisi-kisi soal yang telah dibuat berdasarkan Tema, Standar Kompetensi, Kompetensi Dasar, dan Indikator. Kisi-kisi soal sebagai berikut: merinci pengaruh kalor terhadap perubahan wujud benda, menemukan manfaat perubahan wujud benda dalam kehidupan sehari-hari, menampilkan proses perubahan wujud benda yang terjadi dalam kehidupan sehari-hari, dan memprediksi proses perubahan wujud benda yang terjadi dalam kehidupan sehari-hari

Instrument yang disusun telah memenuhi syarat, perlu dilakukannya uji validitas dan uji reliabilitas. Hal ini dilakukan untuk mendapatkan gambaran yang empiris agar seluruh instrument layak digunakan sebagai instrument penelitian. Uji coba instrument yang digunakan untuk mengetahui kelayakan instrument yang digunakan dalam penelitian ini adalah uji validitas (validitas isi dan validitas butir), uji reliabilitas, uji tingkat kesukaran tes, dan uji daya pembeda tes. Metode analisis data yang digunakan untuk mengetahui hasil belajar IPA siswa kelas $\mathrm{V}$ dalam penelitian ini terdiri atas tiga tahapan yaitu analisis statistik deskriptif, uji prasyarat analisis, dan uji hipotesis.

Uji prasyarat analisis dalam penelitian ini terdiri dari uji normalitas dengan analsis chisquare dan uji homogenitas dengan uji Fisher. Uji normalitas sebaran dilakukan untuk menyajikan bahwa sampel benar-benar berasal dari populasi yang berdistribusi normal. Sedangkan uji homogenitas dilakukan untuk menentukan apakah kelas eksperimen maupun kelas kontrol memiliki penguasaan yang sama atau homogen. Uji hipotesis peneliti menggunakan satu variabel bebas yaitu model pembelajaran Take and Give dan satu variabel terikat yaitu hasil belajar IPA. Hipotesis dalam penelitian ini menggunakan analisi uji-t, penelitian ini hanya membandingkan satu variabel bebas dan satu variabel terika dengan menggunakan dua kelompok sampel.

\section{Pembahasan}

Berdasarkan deskripsi data hasil penelitian pada kelompok siswa yang mengikuti pembelajaran dengan model pembelajaran Take and Give berbantuan media Mind Mapping memiliki hasil belajar yang lebih tinggi dibandingkan dengan kelompok siswa yang tidak dibelajarkan dengan model pembelajaran Take and Give berbantuan media Mind Mapping. Hal ini ditinjau berdasarkan rata-rata skor hasil belajar siswa. Rata-rata skor hasil belajar siswa 
yang peroleh setelah mengikuti proses pembelajaran yang menggunakan model pembelajaran Take and Give berbantuan media Mind Mapping adalah sebesar 19,95. Sedangkan rata-rata skor hasil belajar siswa yang diperoleh setelah mengikuti pembelajaran tanpa menggunakan model pembelajaran Take and Give berbantuan media Mind Mapping adalah sebesar 16,64. Berdasarkan perhitungan uji hipotesis menggunakan uji-t, diketahui bahwa thitung $=3,29$ dan ttabel dengan taraf signifikansi $5 \%=1,714$. Hasil perhitungan tersebut menunjukan bahwa thitung lebih besar dari ttabel (thitung > ttabel), sehingga hasil penelitian ini dinyatakan signifikan. Berdasarkan hasil uji hipotesis, dapat dinyatakan bahwa terdapat pengaruh model pembelajaran Take and Give berbantuan media Mind Mapping terhadap hasil belajar IPA siswa kelas V di Gugus III kecamatan Kubutambahan, Kabupaten Buleleng.

Adanya perbedaan yang signifikan antara siswa pada kelompok eksperimen yang mengikuti pembelajaran dengan menggunakan model pembelajaran Take and Give berbantuan media Mind Mapping dan siswa pada kelompok kontrol yang mengikuti pembelajaran tanpa menggunakan model pembelajaran Take and Give berbantuan media Mind Mapping disebabkan karena adanya perbedaan perlakukan sintak dan penyampaian materi pada masingmasing kelompok. Siswa pada kelompok eksperimen yang mengikuti model pembelejaran Take and Give berbantuan media Mind Mapping mampu lebih cepat memahami materi karena didapatkan melalui teman sebayanya. Hal ini disebabkan karena siswa lebih percaya diri apabila mereka belajar dengan teman sebayanya, sehingga materi yang diberikan atau yang diterima akan lebih jelas dimengerti karena mereka lebih leluasa mengajukan pertanyaan kepada pasangannya apabila ada materi yang belum dimengerti. Dengan mengikuti model pembelajaran ini, siswa menjadi lebih bersemangat dan antusias untuk mengikuti proses pembelajaran. Sedangkan siswa pada kelompok kontrol yang mengikuti pembelajaran tanpa menggunakan model pembelajaran Take and Give berbantuan media Mind Mapping masih berpusat pada guru dan hanya menerima materi yang diberikan oleh guru yang menyebabkan kurangnya partisipasi siswa dalam proses pembelajaran. Hal ini menyebabkan siswa menjadi kurang aktif dan terlihat bosan dalam mengikuti proses pembelajaran. Model Take and Give adalah model pembelajaran yang membuat peserta didik aktif dalam pembelajaran, dimana peserta didik mengambil dan memberi pelajaran pada peserta didik yang lain, sehingga diharapkan peserta didik dapat menguasai lebih banyak materi pelajaran dengan mengajarkan pada teman sebayanya, (Luritawaty, 2018; Sela et al., 2018). Penerapan model pembelajaran Take and Give setiap siswa diminta untuk berdiri dan mencari teman lalu saling menginformasikan tentang materi atau pengetahuannya kepada siswa lain, kemudian mencatat apa yang diperolehnya pada kartu. Dewi, et.al (2014) menyatakan bahwa model Take and Give memiliki kelebihan, yaitu 1) model pembelajaran ini tidak bersifat kaku, karena guru boleh memodifikasi lagi penggunaan model pembelajaran ini sesuai dengan keinginan, kebutuhan, serta situasi pembelajaran, 2) materi akan terarah, karena guru terlebih dahulu menjabarkan uraian materi sebelum kartu dibagikan kepada siswa, 3) melatih siswa dalam bekerja sama dan menghargai kemampuan siswa lain, 4) melatih siswa untuk berinteraksi secara baik dengan teman sekelasnya, 5) dapat meningkatkan tanggung jawab siswa, sebab setiap siswa diminta untuk bertanggung jawab atas kartu yang didapat. Tidak hanya model yang perlu diperhatikan dalam proses pembelajaran namun, adanya media juga akan mendukung keberhasilan dalam proses pembelajaran.

Media pembelajaran adalah seluruh alat dan bahan yang dapat digunakan dalam mencapai tujuan pendidikan seperti radio, televisi, buku, Koran, majalah, dan sebagainya (Arsyad \& Fatmawati, 2018; Tembang et al., 2017; Yenimar, 2017). Media dalam proses pembelajaran dapat membangkitkan minat dan rasa ingin tahu yang baru, menumbuhkan motivasi dan rangsangan kegiatan belajar, serta membawa pengaruh psikologis terhadap pembelajaran (Arisantiani et al., 2017; Khotimah et al., 2020). Media pembelajaran yang sesuai dengan kebutuhan kegiatan pembelajaran akan menciptakan suatu kegiatan pembelajaran yang 
efektif dan efisien sehingga materi yang disampaikan oleh guru kepada siswa bisa diserap secara optimal (Melasarianti et al., 2019; Sapriyah, 2019; Suaeb et al., 2018). Salah satu media yang bisa digunakan adalah media Mind Mapping. Mind Mapping merupakan teknik yang paling baik dalam membantu proses berfikir otak secara teratur karena menggunakan teknik grafis yang berasal dari pemikiran manusia yang bermanfaat untuk menyediakan kunci-kunci universal sehingga membuka potensi otak (I. A. G \& Riastini, 2017; Van Hayus et al., 2014). Pembelajaran dengan mind mapping dapat meningkatkan ingatan dengan cara mengasosiasikan dan mengimajinasikan konsep, serta kata kunci yang saling berhubungan membuat siswa semakin mudah memahami materi (Sartono et al., 2018; Wicaksana, 2012). Mind Mapping dimulai dengan suatu konsep atau tema tunggal yang memiliki banyak pemikiran yang menjadi umpan kepada siswa untuk berpikir dan menghasilkan banyak gagasan mengenai suatu konsep atau tema tunggal tersebut (Darusman, 2014). Pembelajaran mind mapping adalah pembelajaran model baru untuk mencatat yang bekerjanya disesuaikan dengan bekerjanya dua belah otak (otak kiri dan otak kanan) (Rahayu, 2016; Suwitri et al., 2013). Mind Mapping merupakan salah satu teknik yang cocok untuk membantu daya ingat, karena didalamnya sudah terdapat pemetaan pikiran yang memuat kata kunci suatu topik sehingga tidak banyak lagi pembelajaran topik (Arsana et al., 2019; Sugilar, 2013).

Hasil penelitian ini sejalan dengan penelitian yang telah dilaksanakan terlebih dahulu Mutia (2019) penerapan model pembelajaran Take and Give berpengaruh terhadap hasil belajar IPA, selanjutnya penelitian yang dilakukan oleh (Yuliastini et al, 2015) penerapan model pembelajaran Take and Give berpengaruh terhadap hasil belajar IPS, dan (Meda, L. Y., \& Wakidi, 2017) terdapat pengaruh yang signifikan model pembelajaran koopratif tipe Take and Give terhadap hasil belajar siswa kelas X. Berdasarkan penelitian yang telah dilakukan dan diperkuat oleh pemaparan di atas, maka model pembelajaran Take and Give berbantuan media Mind Mapping pada proses pembelajaran berpengaruh signifikan terhadap hasil belajar IPA siswa.

\section{Conclusion}

Berdasarkan hasil uji-t yang telah dilakukan, diperoleh hasil thitung $=3,29$ dan tabel $=$ 1,714 (thitung > ttabel) dengan demikian dapat disimpulkan bahwa terdapat pengaruh yang signifikan model pembelajaran Take and Give berbantuan media Mind Mapping terhadap hasil belajar IPA kelas V Gugus III Kecamatan Kubutambhan, Kabupaten Buleleng tahun pelajaran 2019/2020. Berdasarkan temuan-temuan dalam penelitian ini, dapat disamapaikan saran-saran sebagai berikut. Kepada Siswa, siswa siswi di sekolah dasar agar lebih aktif dalam mengikuti proses pembelajaran dan terus mengembangkan pemahaman dengan membangun pengetahuan melalui pengalaman secara langsung.

\section{References}

Agung, A. A. G. (2014). Buku Ajar Metodologi Penelitian Pendidikan. Aditya Media Publishing.

Arisantiani, N. K., Putra, M., \& Ganing, N. N. (2017). Pengaruh Model Pembelajaran Childrens Learning in Science (Clis) Berbantuan Media Lingkungan Terhadap Kompetensi Pengetahuan Ipa. Journal of Education Technology, 1(2), 124. https://doi.org/10.23887/jet.v1i2.11774

Arsana, I. K., Suarjana, M., \& Arini, N. W. (2019). Pengaruh Penggunaan Mind Mapping berbantuan Alat Peraga Tangga Garis Bilangan terhadap Hasil Belajar Matematika. International Journal of Elementary Education, 3(2), 99-107. https://doi.org/http://dx.doi.org/10.23887/ijee.v3i2.18511

Arsyad, M. N., \& Fatmawati, F. (2018). Penerapan Media Pembelajaran Berbasis Multimedia 
Interaktif Terhadap Mahasiswa IKIP Budi Utomo Malang. Agastya: Jurnal Sejarah Dan Pembelajarannya, 8(2), 188. https://doi.org/10.25273/ajsp.v8i2.2702

Darusman, R. (2014). Penerapan Metode Mind Mapping (Peta Pikiran) Untuk Meningkatkan Kemampuan Berpikir Kreatif Matematik Siswa Smp. Infinity Journal, 3(2), 164. https://doi.org/10.22460/infinity.v3i2.61

Dewi, Asri, Wiyasa, \& K. (2014). Model Pembelajaran Take and Give Berbantuan Media Grafis terhadap Hasil Belajar PKn SD. MIMBAR PGSD Undiksha, 2(1). https://doi.org/http://dx.doi.org/10.23887/jjpgsd.v2i1.2032

I. A. G, S. U., \& Riastini, P. N. (2017). Penerapan Metode Take and Give Untuk Meningkatkan Hasil Belajar Ipa Siswa Kelas Iv. Jurnal Ilmiah Sekolah Dasar, 1(1), 51-58. https://doi.org/http://dx.doi.org/10.23887/jisd.v1i1.10118

Karim, A. (2018). Efektivitas Penggunaan Metode Mind Map Pada Pelatihan Pengembangan Penguasaan Materi Pembelajaran. IJTIMAIYA: Journal of Social Science Teaching, 1(1). https://doi.org/10.21043/ji.v1i1.3098

Khotimah, S. H., Sunaryati, T., \& Suhartini, S. (2020). Penerapan Media Gambar Sebagai Upaya dalam Peningkatan Konsentrasi Belajar Anak Usia Dini. Jurnal Obsesi : Jurnal Pendidikan Anak Usia Dini, 5(1), 676. https://doi.org/10.31004/obsesi.v5i1.683

Luritawaty, I. P. (2018). Pembelajaran Take And Give Dalam Upaya Mengembangkan Kemampuan Pemahaman Konsep Matematis. Mosharafa: Jurnal Pendidikan Matematika, 7(2), 179-188. https://doi.org/https://doi.org/10.31980/mosharafa.v7i2.27

Marliana et al. (2015). Pengaruh Model Pembelajaran Tipe Take And Give Berbatuan Multimedia Pembelajaran Interaktif terhadap Hasil Belajar IPA. E-Journal TP Undiksha, 3(1).

Meda, L. Y., \& Wakidi, W. (2017). Pengaruh Model Pembelajaran Take and Give Terhadap Hasil Belajar Siswa Kelas X. PESAGI. Jurnal Pendidikan Dan Penelitian Sejarah, 5(8).

Melasarianti, L., Krisnawati, V., \& Martha, N. U. (2019). Peningkatan Keterampilan Menulis Puisi Media Gambar Pahlawan Nusantara. JINoP (Jurnal Inovasi Pembelajaran), 5(1), 56. https://doi.org/https://doi.org/10.22219/jinop.v5i1.7785

Mukhid, A. (2007). Meningkatkan Kualitas Pendidikan Melalui Sistem Pembelajaran Yang Tepat.

Tadrîs, 2(1),

$120-133$. http://ejournal.stainpamekasan.ac.id/index.php/tadris/article/view/211/202

Mutia, S. (2019). Pengaruh Model Pembelajaran Take And Give Terhadap Hasil Belajar Ipa Kelas V SD Negeri 101874 Tumpatan Nibung Kecamatan Batang Kuis. Universitas Islam Negeri Sumatera Utara.

Rahayu, R. (2016). Peningkatan Karakter Tanggung Jawab Siswa Sd Melalui Penilaian Produk Pada Pembelajaran Mind Mapping. Jurnal Konseling Gusjigang, 2(1). https://doi.org/10.24176/jkg.v2i1.562

Ratih Sulistyastuti, D. (2007). PEMBANGUNAN PENDIDIKAN DAN MDGs DI INDONESIA Sebuah Refleksi Kritis. Jurnal Kependudukan Indonesia, 2(2), 19-44. http://ejurnal.kependudukan.lipi.go.id/ojs248jki/index.php/jki/article/view/146/179

Sapriyah. (2019). Peran Media Pembelajaran Dalam Proses Belajar Mengajar. Diklat Review : Jurnal Manajemen Pendidikan Dan Pelatihan, 3(1), 45-56. https://doi.org/10.35446/diklatreview.v3i1.349

Sartono, N., Komala, R., \& Dumayanti, H. (2018). Pengaruh Penerapan Model Reciprocal 
Teaching Terintegrasi Mind Mapping Terhadap Pemahaman Konsep Siswa Pada Materi Filum Arthropoda. Biosfer: Jurnal Pendidikan Biologi, 9(1), 20-27. https://doi.org/10.21009/biosferjpb.9-1.4

Sela, S., Akip, M., \& Permatasari, R. (2018). Penerapan Model Pembelajaran Take and Give Untuk Meningkatkan Aktivitas Belajar Siswa Pada Mata Pelajaran Ipa Di Kelas Ii Sd. Jurnal Pendidikan Dasar, 6(2), 93-100. https://doi.org/10.46368/jpd.v6i2.146

Suaeb, S., Degeng, I. N. S., \& Amirudin, A. (2018). Meningkatkan Hasil Belajar IPS Siswa Kelas V melalui Penerapan Pembelajaran Kooperatif Model Teams Games Tournament ( TGT ) Berbantuan Media Tebak Gambar. Jurnal Pendidikan: Teori, Penelitian, Dan Pengembangan, $3(1)$, 146-154. https://doi.org/http://dx.doi.org/10.17977/jptpp.v3i1.10435

Sugilar, H. (2013). Meningkatkan Kemampuan Berpikir Kreatif Dan Disposisi Matematik Siswa Madrasah Tsanawiyah Melalui Pembelajaran Generatif. Infinity Journal, 2(2), 156. https://doi.org/10.22460/infinity.v2i2.32

Suwitri, N. P. D., Ardana, I. K., \& Negara, I. G. A. O. (2013). Pengaruh Pembelajaran Mind Mapping Berbantuan Media Konkret Terhadap Hasil Belajar IPA Siswa Kelas V SD Gugus III Banjar Anyar Kediri. Mimbar PGSD, 1(1). https://doi.org/http://dx.doi.org/10.23887/jjpgsd.v1i1.1251

Tembang, Y., Sulton, \& Suharjo. (2017). Peningkatan Motivasi Dan Hasil Belajar Melalui Model Pembelajaran Think Pair Share Berbantuan Media Gambar Di Sekolah Dasar. Jurnal Pendidikan, 2(6), 812-817.

Van Hayus, E. S., Apriyanto, D., \& Mulyani, S. (2014). Pengaruh Metode Pembelajaran Mind Mapping Dan Kemampuan Memori Siswa Terhadap Prestasi Belajar Kimia Pada Pokok Bahasan Hukum-Hukum Dasar Kimia Pada Siswa Kelas X Semester Gasal Di Sma Negeri 1 Mojolaban Tahun Pelajaran 2012/ 2013. Jurnal Pendidikan Kimia, 3(3), $1-10$.

Wicaksana, R. B. (2012). Penerapan Pembelajaran IPA dengan Strategi Mind Mapping (Peta Pikiran) Terhadap Hasil Belajar Siswa Pada Materi Ekosistem Kelas VII SMPN 3 Madiun. Pensa E-Jurnal, 9-25. http://ejournal.unesa.ac.id/article/333/37/article.pdf

Yenimar. (2017). Meningkatkan Hasil Belajar IPS Siswa Melalui Penggunaan Media Gambar. Jurnal EDUCATIO: Jurnal Pendidikan Indonesia, 3(2), 44. https://doi.org/10.29210/12017296

Yuliastini et al. (2015). Pengaruh Model Pembelajaran Take And Give Berbatuan Multimedia Interaktif terhadap Hasil Belajar IPS. E-Journal TP Undiksha, 3(1). https://doi.org/http://dx.doi.org/10.23887/jeu.v3i1.5599 